\title{
MIR146B Gene
}

National Cancer Institute

\section{Source}

National Cancer Institute. MIR146B Gene. NCI Thesaurus. Code C81779.

This gene is involved in the regulation of gene expression and plays a role in the development of carcinoma of the breast and glioma. 